\title{
Quality, prices and production efficiency: an exploratory study of Italian wines with appellation of origin
}

\author{
Pier Paolo Miglietta*, Domenico Morrone**
}

DOI: $10.30682 / \mathrm{nm} 1801 \mathrm{~g}$

JEL codes: O13, Q13, Q18

\begin{abstract}
Wine is a complex and highly differentiated product of a very wide and heterogeneous compartment, where quality plays an important role in determining demand.

Wine production in Italy is unique in the world and important for all of its regions and its vineyards are placed in extremely different environments, from coastal plains to considerable altitudes and slopes. The Italian level of quality can be considered very high, since approximately $69 \%$ of wine production is characterized by Appellation of Origin (AO).

The main purpose of this study is to evaluate the potential efficiency in production of Italian wines with Appellation of Origin, in terms of quality, prices and vine yields.

Results of this study highlight the economic value generated annually by each declared hectare of vineyard, showing the "Top five wines", allowing reflections that underline the strategic role of some factors, useful to create a high value production process.
\end{abstract}

Keywords: Wine, Appellation of origin, Italy, Prices, Efficiency.

\section{Introduction}

Wine surely cannot be considered a new product, since its origins date back thousands of years b.C.. It is a complex and highly differentiated product of a very wide, heterogeneous and articulated compartment, where quality plays an important role in determining demand.

Although wine is not considered an essential food for human nutrition, it has always influenced the economy of the wine-producing countries thanks to its symbolic values, full of social and cultural meanings (Miglietta et al., 2015).

World wine production is very remarkable. It is around 267 million hectolitres, considering the last data available referring to 2016 (OIV, 2017).
However, the wine market represents a challenging global market with an evident contraposition between the Old World producing countries and the New World ones, as stated by Campbell et al. (2006). The first group is the production leader where only three countries, respectively Italy, France and Spain, contribute to the half of the entire volume, thanks to a long tradition in this sector. But in the Old World consumption is decreasing, differently from the New World, where production and, above all, consumption are increasing, showing interesting numbers. For example the U.S. is the fourth producer with 23,9 million hectolitres, but the first consuming country with 31,8 million hectolitres. Other important consuming countries

* Department of Economics and Management, University of Salento, Lecce, Italy.

** Department of Management, LUM University, Casamassima (BA), Italy.

Corresponding author: morrone@lum.it. 
of the New World are China (17,3 mln. hl), Argentina $(9,4 \mathrm{mln} . \mathrm{hl})$, Australia $(5,4 \mathrm{mln} . \mathrm{hl})$, Canada (5,0 mln. hl) and Japan (3,5 mln. hl) (OIV, 2017). This means increasing competition (Malorgio et al., 2008), where export activity plays a strategic role.

Therefore, the current overview of the international wine market shows, as stated by Hussain et al. (2007), the radical and rapid change of competitive positions and consumption patterns in the Old and New World countries.

Consequently, the global wine market has become more complex, also considering the evolution of the way of consumption. It is important to reflect not only in terms of volumes sold, but we even have to consider all variables that may affect consumer behaviour.

Following the analysis of Smith et al. (2007), several factors may influence wine consumption. They could be the general economic conditions (where homogeneity is increasing according to Kustin and Mitry (2003) and Smith and Solgaard (1997)), such as a developing health consciousness that drives consumers to more fashionable and healthful beverages.

Regarding the wine purchasing decision, Schamel (2006) identifies a positive effect coming from expert opinions or producer quality signals too, for example a regional differentiation (reinforced by the protection of geographical indications). In particular, the strong connection with the territory is one of the most important contexts to attract consumer preferences, as tested by the very well-known issue of territorial identity. Following the best example related to French wine with terroir, it demonstrated that the place of origin can evoke authenticity, as a presupposition for quality (Gade, 2004).

Therefore, all these circumstances continuously lead wineries to look for efficiency in every stage of production and selling, from the agricultural phase to promotional activity. The ultimate goal is to strengthen the different features of this beverage to underline its qualities. Thanks to technological progress you can measure and improve the quality of the wines produced through finesse, intensity, and originality in taste and smell and by microbiological and physicochemical stability (Colagrande et al., 1994; Dubourdieu, 1986; Noble, 1988; Rapp et al., 1986; Schreier et al., 1979).
Considering the international market, wine producers need to put economic efficiency as one of the most important evaluations for their activity. The former is a wide concept that includes price and technical efficiency, as stated by de Sousa Henrique et al. (2009). From this point of view the perfect match that has to be reached among costs, production, sales and consumer preferences, to build the best value for wine is clear.

The aim of this study is to calculate the production efficiency of Italian wines with an Appellation of Origin (AO) in terms of value attained by each vineyard area, investigating the relation between yields and prices as representation not only of technical process factors, but also of economical aspects and territorial identities. The choice of $\mathrm{AO}$ wines is, in fact, motivated by the particular features they represent, with a particular meaning considering the market evolution and the commitment towards sustainable development direction.

The paper is organized as follows: Section 2 provides a background on quality features in the Italian wine market with a focus on regional differences. Section 3 is devoted to discussing the data used, the overall logical framework and methodology. Section 4 presents the discussion of results and Section 5 concludes.

\section{Background}

\subsection{Wine quality and the territorial identity}

In the last few years the evolution of international wine markets has expressed a highly fragmented offer of products and relative labels (Bruwer, 2004). Therefore the imperative of differentiation to reach a desirable position in consumer preferences is not so simple. Following this direction, above all for wine, the identification with the place of origin may be one of the best possible business strategies (Thode and Maskulka, 1998). The growing importance of territory has been demonstrated through the consumers' willingness to pay higher prices for wines produced in a famous area, even if they do not have enough information related to quality (Schamel, 2006). This relation has been very well interpreted, as above mentioned, from the concept of terroir, identifying, according Vaudour (2002), different aspects like variety of plants, 
typical foods, territory, strategies of advertising and marketing. Moreover, he underlines that, considering the sustainable production and the evolution of the wine market (Hardie, 2000; Corino and Calo, 2001), the connection with the territory is the way to represent the features of the place of origin through distinguished wines. Currently it is possible to affirm that the territorial identity is becoming a real competitive advantage in wine marketing policies (Rocchi and Gabbai, 2013). This strategic feature has been accepted not only by the Old World producers but also by New World ones, who definitely recognize it as an instrument for quality differentiation (Camanzi et all., 2017).

Summarizing, geographic branding can be settled in a relationship with quality and sustainability (Warner, 2007), including social, economic and environmental aspects. When aiming to reach a high position in the market, the connection between the place of production and quality is an obliged element (Beverland, 2005, 2006). Moreover, considering the limits imposed by the Appellation of Origin in terms of production restrictions (yield, territories, etc.), this certification often becomes, analyzing other agro-food sectors, a real non-tariff barrier (Chambolle and Giraud-Héraud, 2005). For this reason a structured strategy is fundamental. Surely, analyzing the place of origin and the quality of production is strictly connected with different environmental elements as soil, climate and other physical elements (Costantini et al., 2016; Costantini and Bucelli, 2014; Van Leeuwen and Seguin, 2006) and an efficient vertical relationship between the phases of production and processing is important too (Malorgio et al., 2013).

Table 1 - Wine Production by Italian Region (volumes in thousands of hectoliters).

\begin{tabular}{|l|c|c|c|c|c|c|}
\hline Region & 2012 & 2013 & 2014 & 2015 & 2016 & $\%$ Var 2012-2016 \\
\hline Abruzzo & 2,443 & 2,728 & 2,273 & 2,936 & 2,937 & $20 \%$ \\
\hline Basilicata & 189 & 178 & 102 & 87 & 93 & $-51 \%$ \\
\hline Calabria & 400 & 370 & 314 & 404 & 391 & $-2 \%$ \\
\hline Campania & 1,542 & 1,644 & 1,183 & 1,614 & 1,286 & $-17 \%$ \\
\hline Emilia Romagna & 6,273 & 7,396 & 6,958 & 6,752 & 7,039 & $12 \%$ \\
\hline Friuli-Venezia Giulia & 1,281 & 1,073 & 1,367 & 1,872 & 1,856 & $45 \%$ \\
\hline Lazio & 1,365 & 1,571 & 1,302 & 1,676 & 1,523 & $12 \%$ \\
\hline Liguria & 46 & 46 & 63 & 79 & 63 & $37 \%$ \\
\hline Lombardia & 1,222 & 1,301 & 1,424 & 1,410 & 1,421 & $16 \%$ \\
\hline Marche & 918 & 1,039 & 915 & 959 & 959 & $4 \%$ \\
\hline Molise & 319 & 319 & 297 & 232 & 232 & $-27 \%$ \\
\hline Piemonte & 2,366 & 2,580 & 2,402 & 2,467 & 2,549 & $8 \%$ \\
\hline Puglia & 5,338 & 5,908 & 5,430 & 7,313 & 8,792 & $65 \%$ \\
\hline Sardegna & 503 & 638 & 746 & 794 & 804 & $60 \%$ \\
\hline Sicilia & 5,169 & 7,282 & 4,539 & 5,476 & 5,323 & $3 \%$ \\
\hline Toscana & 2,098 & 2,657 & 2,778 & 2,825 & 2,738 & $31 \%$ \\
\hline Trentino-Alto Adige & 1,210 & 1,362 & 1,029 & 1,230 & 1,140 & $-6 \%$ \\
\hline Umbria & 637 & 706 & 670 & 765 & 814 & $28 \%$ \\
\hline Valle d'Aosta & 17 & 20 & 15 & 14 & 15 & $-12 \%$ \\
\hline Veneto & 7,740 & 9,148 & 8,281 & 9,733 & 10,145 & $31 \%$ \\
\hline Italy & $\mathbf{4 1 , 0 7 4}$ & $\mathbf{4 7 , 9 6 6}$ & $\mathbf{4 2 , 0 8 8}$ & $\mathbf{4 8 , 6 3 5}$ & $\mathbf{5 0 , 1 1 8}$ & $\mathbf{2 2 \%}$ \\
\hline Source based & & & & & \\
\hline
\end{tabular}

Source: based on data from Italian Wine Central (2017a). 


\subsection{The $A O$ wine Italian production}

Wine production in Italy is unique in the world and important for all of its regions and its vineyards are placed in extremely different environments, from coastal plains to considerable altitudes and slopes (Miglietta et al., 2013; De Leo et al., 2015).

Figure 1 - Wine Production in Italy and quality level in 2016 ( $\%$ of the total volumes produced in each Region).

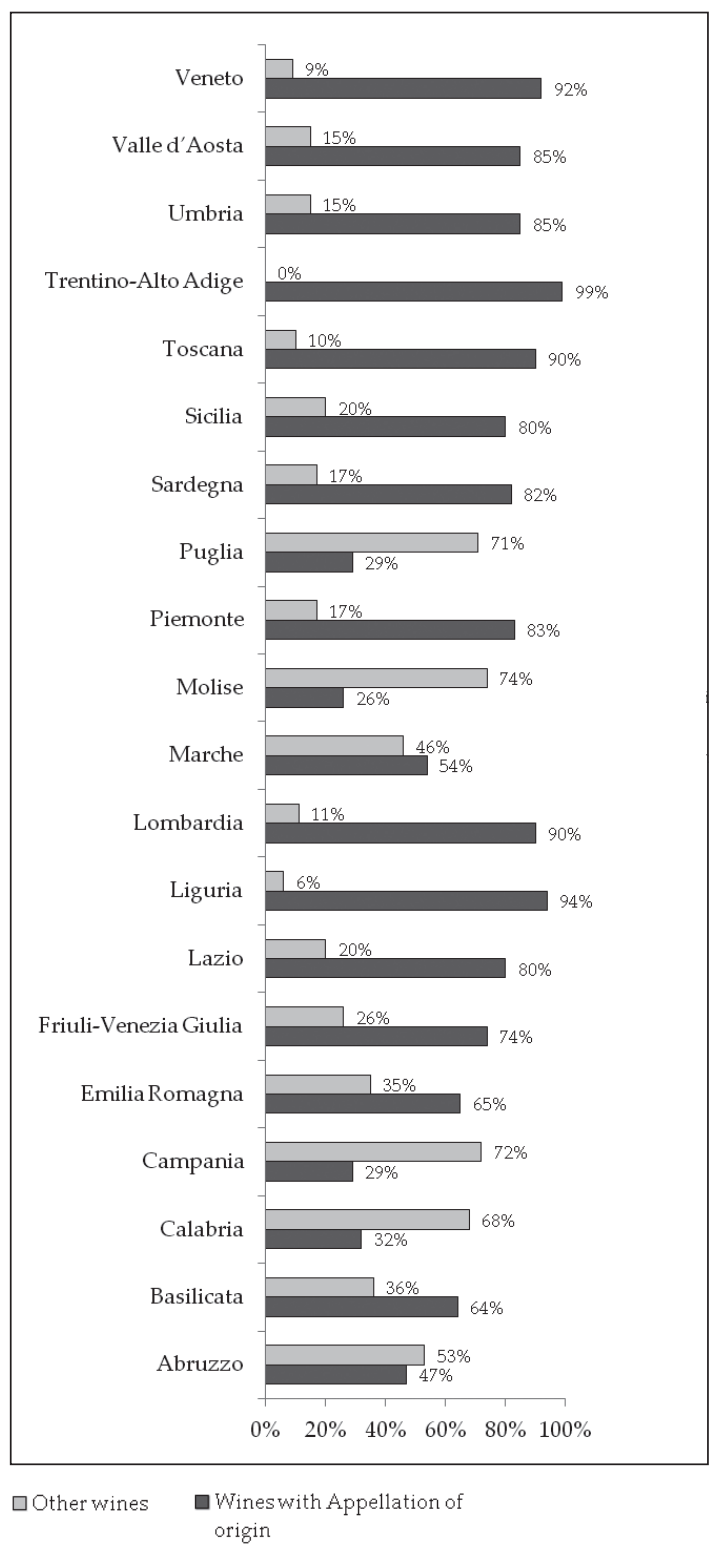

Source: based on data from Italian Wine Central (2017b).
Since approximately $69 \%$ of wine production is characterized by Appellation of Origin (AO), the Italian level of quality can be considered very high. As we can see from Table 1, Regions with the highest production volumes in 2016 are Veneto $(10,145$ thousand of hectoliters), Puglia $(8,792$ thousand of hectoliters), Emilia-Romagna (7,039 thousand of hectoliters) and Sicily (5,323 thousand of hectoliters).

Puglia and Sardegna are the best performing regions in terms of percentage of variation between 2012 and 2016, registering increasing values of production over $60 \%$, beyond the Italian average of $22 \%$. The two worst regions are Basilicata and Molise which have registered in the five-year period respectively $-51 \%$ and $-27 \%$ in their total production of wine.

Nevertheless, if we consider wine quality, each region has a different productive performance, whose ranking differs from the above figures based only on quantitative parameters.

As we can see in Figure 1, in Puglia 71\% of production is destined to generic wines, while only $29 \%$ to the production of wines with AO (in particular PDO - Protected Designation of Origin and PGI - Protected Geographical Indication); in Veneto the situation is completely reversed, $92 \%$ of its wine production, accounting for $27 \%$ of AO Italian wine production and almost $19 \%$ of the total, is destined to PDO and PGI wines.

\section{Materials and methodology}

The main aim of this study is to evaluate the potential efficiency in production of $\mathrm{AO}$ wines, in terms of quality, prices and vine yields and the related efficiency trend.

The research design adopted is a secondary data analysis. Existing quantitative datasets have been used as data sources to realize an analysis and to verify our hypothesis.

The panel data used for the purposes of this study has been constructed based on FEDERDOC reports (Federdoc, 2012; 2013; 2014; 2015; 2016), used for the dissemination of statistics on wine production with Appellation of origin and ISMEA data (ISMEA, 2017). Federdoc is the National confederation of volunteer consortium 
for the protection of Italian wines with Appellation of Origin. It publishes yearly the so-called "V.Q.P.R.D. d'Italia", which contains data relating to the production of wines with Appellation of Origin in Italy on the basis of surveys provided by some supervisory structures.

Ismea (Istituto di servizi per il mercato agricolo alimentare), instead, is a public entity, controlled by the Ministry of Agricultural, Food and Forestry Policies, part of the SISTAN (National Statistics System) and of SIAN (National Agricultural Informative System).

For the scope of this study, a sample of 65 Italian wines with Appellation of Origin was selected among wines whose variables chosen for this research have been previously observed and were annually available for the analyzed period of time.

For this reason, not every AO Italian wine has been considered in this analysis, because of the lack of data.

The time series included in this research goes from 2011 up to 2015 and it does not go further because the years 2011 and 2015 are the only years when complete and reliable data for the variables used in our framework could be found.

In particular, the analysis is based on three fundamental variables: wine production, declared surface of grapes, and wine prices. These variables have been selected as the most important factors affecting economic and technical efficiency, since they include quality attributes, vine and grape yields related to cultivation and winemaking methods, market and consumption-driven aspects. Appendices 1, 2 and 3 report time series of these variables for each $\mathrm{AO}$ wine considered in the study.

The first variable, wine production has been measured by the production data, expressed as hectoliters of wine produced. The second variable, declared surface of grapes, has been measured by the extension in hectares used for the specific viticulture. The third variable, wine prices, has been measured by the average annual prices at source, i.e. the prices paid to producers on average in a year for a specific wine with Appellation of Origin, expressed in Euro/hectoliters, used as proxy for capturing not only tangible, but also intangible values, mainly imputable to territorial identity.

The methodological approach of this study consists of five steps. In the first, data on the wine production and declared surface of grapes related to the 65 Italian wines with AO were collected and analyzed for the five-year period 2011-2015 (Federdoc, 2012; 2013; 2014; 2015; 2016), and then integrated with average annual wine price (ISMEA, 2017).

In the second step, descriptive statistics of each variable considered in this study were illustrated and a correlation matrix based on Pearson's coefficient was calculated.

In the third step, we proceeded with the calculation of the production efficiency of AO wines, i.e. the value generated annually by each declared hectare of vines in the geographic areas interested by typical production, by the equation:

$$
E f f_{\text {wine }}=\frac{\text { Prod }_{\text {wine }} \times \text { Price }_{\text {wine }}}{\text { Area }_{\text {vineyards }}}
$$

where:

Prod $_{\text {wine }}$ indicates the production of wine, expressed in hl;

Price $_{\text {wine }}$ represents the average annual producer prices in $€ / \mathrm{hl}$;

Ares $_{\text {wineyards }}$ is the area expressed in terms of declared ha of grape.

After the calculation of the economic value generated by the areas under vines $\left(E f f_{\text {wine }}\right)$, in the fourth step a ranking was drawn up to highlight the top five AO wines in 2015, in order to capture potential specifications that characterize attitudes or attributes of these competitive productions.

Finally, in order to respond to the purpose of this study, the change rate of the Eff wine between 2011 and 2015 was computed in order to capture efficiency trend.

\section{Results and discussions}

Descriptive statistics for the variables mentioned in the materials and methods section and collected in the Appendices 1, 2 and 3 are illustrated below in Table 2.

Before proceeding with the calculation of production efficiency of AO wines, Pearson's coefficients were calculated in order to detect correlation between variables (Table 3 ).

The correlation matrix highlights a strong relation between declared vineyards and $\mathrm{AO}$ wine 
Table 2 - Descriptive statistics of the variables used for the analysis for each year from 2011 to 2015.

\begin{tabular}{|c|c|c|c|c|}
\hline & & Wine production $(1,000 \mathrm{hl})$ & Declared surface of grapes (ha) & Wine price $(€ / \mathrm{hl})$ \\
\hline \multirow{4}{*}{2011} & Mean & 172 & 2,367 & 118 \\
\hline & St. Dev. & 235 & 2,823 & 100 \\
\hline & Min & 4 & 107 & 34 \\
\hline & Max & 1,351 & 14,645 & 617 \\
\hline \multirow{4}{*}{2012} & Mean & 175 & 2,432 & 130 \\
\hline & St. Dev. & 273 & 2,968 & 112 \\
\hline & Min & 5 & 82 & 51 \\
\hline & Max & 1,798 & 14,285 & 677 \\
\hline \multirow{4}{*}{2013} & Mean & 186 & 2,459 & 139 \\
\hline & St. Dev. & 307 & 3,176 & 115 \\
\hline & Min & 6 & 81 & 54 \\
\hline & Max & 2,141 & 17,490 & 710 \\
\hline \multirow{4}{*}{2014} & Mean & 183 & 2,466 & 139 \\
\hline & St. Dev. & 321 & 3,326 & 121 \\
\hline & Min & 2 & 46 & 44 \\
\hline & Max & 2,241 & 19,108 & 755 \\
\hline \multirow{4}{*}{2015} & Mean & 213 & 2,655 & 153 \\
\hline & St. Dev. & 473 & 3,776 & 138 \\
\hline & Min & 4 & 63 & 44 \\
\hline & Max & 3,648 & 23,979 & 880 \\
\hline
\end{tabular}

Table 3 - Correlation matrix based on Pearson's coefficients for each variable considered in the analysis.

\begin{tabular}{|r|c|c|c|}
\hline & Wine production & Declared surface of grapes & Wine price \\
\hline Wine production & 1.000 & 0.914 & 0.002 \\
\hline Declared surface of grapes & & 1.000 & 0.054 \\
\hline Wine price & & & 1.000 \\
\hline
\end{tabular}

Critical value at $5 \%$ (for two tails) $=0,1088$ for $n=325$

production, which is equal to 0.914 and could be intuitively hypothesized. This relation is in fact strictly linked to the yields not only in terms of grapes produced by a certain vineyard area (crop yields), but also to the yields in terms of quantity of wine produced by a certain quantity of grapes (technical process yields).

The values of Pearson's coefficient for the relation between wine prices and wine production or declared area of grapes, which are approximately close to 0 , underline a weak correlation, explained by the fact that wine prices, contrarily to other agrifood products, capture other factors than the classical ones, such as supplied and demanded quantity.

Wine prices include intangible values, which are not merely connected with crop or technical processes, but are more linked to the concept of terroir mentioned in the background subsection.

Including wine prices in the production efficiency assessment of AO wines, as illustrated in the materials and methods section, helps in strengthening our results. 
Table 4 - Top five Italian wines with Appellation of Origin in terms of annual production efficiency expressed in $€ /$ ha and percentage variation between 2011 and 2015 .

\begin{tabular}{|c|l|c|c|c|c|c|c|}
\hline Position & \multicolumn{1}{|c|}{ Appellation of Origin } & 2011 & 2012 & 2013 & 2014 & 2015 & $\begin{array}{c}\% \text { change } \\
\text { rate 2011- } \\
2015\end{array}$ \\
\hline 1 & Barolo & 27,259 & 33,901 & 35,139 & 32,790 & 38,350 & $41 \%$ \\
\hline 2 & Brunello di Montalcino & 22,816 & 26,545 & 28,178 & 30,279 & 36,779 & $61 \%$ \\
\hline 3 & Prosecco & 19,154 & 19,509 & 14,690 & 13,605 & 26,775 & $40 \%$ \\
\hline 4 & Conegliano Valdobbiadene & 17,444 & 19,067 & 18,440 & 18,109 & 20,642 & $18 \%$ \\
\hline 5 & Vino Nobile di Montepulciano & 14,053 & 13,281 & 18,348 & 18,211 & 19,033 & $35 \%$ \\
\hline
\end{tabular}

Figure 2 - Efficiency trend of the top five Italian wines with Appellation of Origin in $€ /$ ha between 2011 and 2015.

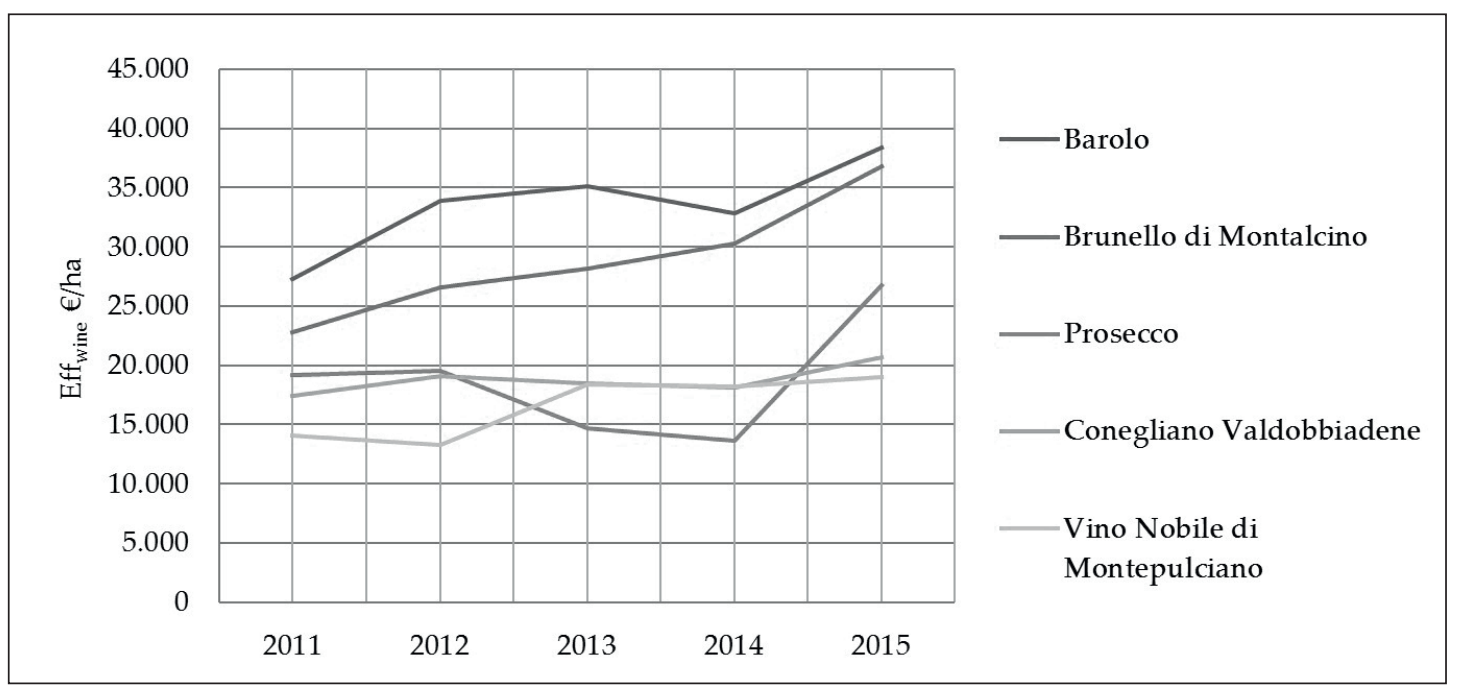

Table 4 and Figure 2 indicate the economic value generated annually by each hectare declared (in absolute terms), showing the "Top five wines" and their trends. Through these data it is possible to make some reflections that underline the strategic role of some above-mentioned factors, useful to create a high value proposition. These factors are, to cite the most important, technical efficiency as well as valorization, marketing and promotion activities.

Wines named "Barolo", "Brunello di Montalcino" and "Vino Nobile di Montepulciano" are not a surprise in this ranking, since they represent the crown jewels of the Italian wine panorama. They come from the well-known Italian regions dedicated to this kind of production, Piedmont and Tuscany. These wines were some of the first wines launched in the national and foreign markets. The ongoing work of promotion has been also carried out thanks to the relevant contribution of consortia, which grouping all wineries, protect the image and the tradition, strictly connected with the origin territories.

In particular, the "Consortium for the Protection of Quality of Local Wines Barolo and Barbaresco" is one of the most ancient, founded in 1934, in the first decades of the last century. It is not a coincidence that currently Barolo is the wine with the "best value" in the proposed elaboration and was also mentioned in the book The best Italian wines since 1908 (Strucchi, 1908). These three above-mentioned typologies have reached these positions mostly for the efficiency of intangible assets. They did not receive a clear support from 
the efficiency in production. Evaluating the first and the last year of the observations, Barolo registered a slight increase of the declared area $(+7 \%)$, corresponding, substantially, to the same increasing level of production $(+8 \%)$. On the contrary, the value of production per hectare has significantly developed $(+41 \%)$, thanks to the positive trend of the prices $(+39 \%)$.

On the same level are the results of Brunello di Montalcino, where it is possible to observe a better but marginal influence of efficiency in production. A non-relevant increase in cultivation areas $(+2 \%)$ was followed by a good result in production $(+15 \%)$ but, also in this case, the main reason for the growth of the value generated per hectare $(+61 \%)$ must be attributed to the higher prices $(+43 \%)$.

A particular case is Vino Nobile di Montepulciano. The reduction of the declared area in the five-year period $(-7 \%)$ has been accompanied by a worsening in production capacity $(-13 \%)$ but, thanks to a very positive trend of the prices $(+44 \%)$, the final result is still more than interesting $(+35 \%)$.

Conegliano Valdobbiadene followed the same direction of the above-mentioned wines. Definitively there is a balanced increase of area and production (respectively $+25 \%$ and $+27 \%$ ), while the value produced for each hectare $(+18 \%)$ can very well explained by the price increase $(+17 \%)$.

A final consideration, not in order of importance, is given to Prosecco. It registered very important sales. In general the entire sparkling wine sector has seen a positive trend in recent years, but Prosecco is gaining ever-larger market shares. For this typology the double influence in the final result $(+40 \%)$ of price evolution $(+11 \%)$ and, even more, the efficiency in production is evident. The remarkable increase in the declared areas $(+114 \%)$ has been followed by a more substantial increase in production $(+170 \%)$.

The results shown represent clear evidence of the great value that an $\mathrm{AO}$ wine could reach, in terms of quality and revenues. In the Italian territory there are a lot of other AO productions that could follow the same direction, since in the past decades there has been an evident lack of strategic policies for different varieties, missing out on all of the opportunities coming from a wonderful heritage.
An example could be "Marsala". This is a very ancient wine from west coast of Sicily, where the earliest traces of an international trade between Sicily and England date back even to the end of the seventeenth century. After this first development, there was an important story related to this wine, strictly connected with the local development. Unfortunately, some wrong choices caused a strong loss of value, mostly during the ' 60 s and '70s. In that period, considerable quantities of Marsala were produced with different non-original flavors, altering the originality of the wine. Moreover, the same "production regulations" still today provide too many varieties, which is not good for defining a precise identity of Marsala (Carrera, 2013). In the last five years, the attention to quality and to consumer preferences, totally oriented to originality without modifications, have been sending a clear signal, verifiable through the average price that has had significant growth, going from 66 Euro in 2011 to 115 Euro in 2015 for each hectolitre, with an increase of 74\% (Appendix 3).

\section{Conclusions}

The proper policies to restore the real wine identity are giving the first positive results in Italy, but there is still a long complex path to be followed. In this context the case of French wines can be considered emblematic. In 2015 the real total wine production in France was about $47 \mathrm{mln}$. hl, compared to $50 \mathrm{mln}$. hl of Italy (OIV, 2017). Despite this imbalance based on quantities produced, French wines were able to create a total value of 27.5 bn Euro, while Italian ones stopped at 13.4 bn Euro, less than half. This means that the real challenge for the Italian wine industry should be focused on the territorial identity in terms of efficiency, quality production, originality and promotion (INDV, 2017).

When investigating the ability of viticulture to combine input and output variables of the grape production processes, the level of efficiency assumes relevance, not only to policy makers, but also to farmers, who can benefit and base their business strategies on the efficiency results.

Producing AO wines is profitable in economic terms, given the high added value associated with 
product itself, but the association between quality, prices and productive efficiency is still up for debate (De Leo et al., 2015). Our study has focused on the assessment of AO wines, analyzing their performance in terms of economic values originated from areas under vines.

From this analysis it is clear that, particularly in some cases, grapevine adaptation to the traditional areas of production allows for the use of fewer resources than those that, in theory, are required, assuring sustainability from an economic productivity based view (Toma et al., 2016). Strengthening the production of these $\mathrm{AO}$ wines would lead to an increase in the economic values generated by the sector, allowing plants to produce adequate quantities of grapes with fewer dedicated areas, focusing on higher yields in terms of grapes produced and related wine production, assuring efficiency, sustainability and nutritional quality of the final product.

With reference to typical products, local actors should develop strategies able to generate economic and environmental value on the basis of the specific characteristics of the territory, thus becoming a potential resource for the rural system through the creation of the value generated by the product itself (Tregear et al., 2007; Marescotti, 2003).

In a modern marketing policy view, it is clear, in fact, that the fundamentals of sustainability cannot be omitted, and that the profit objective has to be balanced with environmental bounds (Morrone, 2012).

Moreover, the continuous work to promote wines and their territories produces an interesting value not only for wines, but also for the lands located in the areas delimited by AO wine specifications. It is a true virtuous circle that is possible to generate. In fact, analyzing the average prices of the land values related to vineyards (used to produce both wine and fruit to eat) found in the regions of the five above-mentioned wines, the increasing results supported by Barolo and Conegliano are evident. In fact, these had, respectively, a growth of $9 \%$ and 14\%, from 2011 to 2015 (CREA, 2017).

Although this work has already widened the approach to land use indicator linked to the agricultural process, in order to improve the concept of productivity in an environmental context, future studies could also update the results of this paper, extending the assessment to other geographical and agriculturally relevant areas, analyzing the impact of other environmental variables on efficiency using parametric and non-parametric models (Toma et al., 2017).

In this perspective, further research should be addressed to assessing the environmental footprints of wine production and trade to test the productive specialization of different areas around the world, from a natural resource sustainability approach.

\section{Acknowledgements}

The authors would like to thank Mariateresa Santaloia and Traci Michelle Ricciardo for the extensive English revisions.

\section{References}

Beverland M.B., 2005. Crafting brand authenticity: The case of luxury wines. Journal of management studies, 42(5): 1003-1029.

Beverland M., 2006. The 'real thing': Branding authenticity in the luxury wine trade. Journal of Business Research, 59(2): 251-258.

Bruwer J., 2004. The Love Affair of Generation-X Consumers with the Winery Cellar Door. Australian and New Zealand Grapegrower and Winemaker, 19-24.

Camanzi L., Grazia C., Giraud-Héraud E. and Malorgio G., 2017. Quality differentiation in the Italian wine industry: terroir-based vc. Brand-based strategies. Int. J. Globalisation and Small Business, Vol. 9, Nos. 2/3.

Campbell G. and Guibert N., 2006. Introduction: Old World strategies against New World competition in a globalising wine industry. British Food Journal, 108(4): 233-242.

Carrera F., 2013. Rivalutare (il) Marsala, http://www. cronachedigusto.it/archiviodal-05042011/325-scenari/11076-rivalutare-il-marsala.html (accessed 31 July 2017).

Chambolle C., and Giraud-Héraud E., 2005. Certification of Origin as a Non-Tariff Barrier. Review of International Economics, 13(3): 461-471.

Colagrande O., Silva A. and Fumi M.D., 1994. Recent applications of biotechnology in wine production. $\mathrm{Bi}$ otechnology Progress, 10(1): 2-18.

Corino L. and Calo A., 2001. Sustainable viticulture: current practices and future developments. Agriculturae Conspectus Scientificus, 66(1): 3-11.

Costantini E.A.C. and Bucelli P., 2014. Soil and terroir. In: Kapur S. and Erşahin S. (eds.), Soil Security for 
Ecosystem Management., Cham: Springer International Publishing, 97-133.

Costantini E.A.C., Lorenzetti R. and Malorgio G., 2016. A multivariate approach for the study of environmental drivers of wine economic structure. Land Use Policy, 57: 53-63.

CREA, 2017. Indagine sul mercato fondiario, http://antares.crea.gov.it:8080/mercato-fondiario/banca-dati (accessed 27 October 2017).

De Leo F., Miglietta P.P. and Massari S., 2015. Water sustainability assessment of Italian vineyards: doc vs. generic wines. Proceedings of Contemporary Trends and Perspectives in Wine and Agrifood Management, Lecce, Italy, 16-17 January.

De Leo F., Miglietta P.P. and Toma P., 2013. Il 'virtual water trade balance'come indicatore di sostenibilità del settore vitivinicolo italiano. In: Guido G. and Massari S. (eds). Lo Sviluppo Sostenibile. Ambiente, Risorse, Innovazione, Qualità. Milano: FrancoAngeli, 485-496.

De Leo F., Miglietta P.P. and Massari S., 2015. Water sustainability assessment of Italian vineyards: doc vs. generic wines. Proceedings of Contemporary Trends and Perspectives in Wine and Agrifood Management, Lecce, Italy, 16-17 January.

de Sousa Henriques P.D., da Silva Carvalho M.L. and de Sousa Fragoso R.M., 2009. Technical efficiency of Portuguese wine farms. New Medit, 8(1): 4-9.

Dubourdieu D., 1986. Wine technology: current trends. Cellular and Molecular Life Sciences, 42(8): 914-921.

Federdoc, 2012-2016. V.Q.P.R.D. d'Italia - I vini italiani a Denominazione d'Origine, http://www.federdoc. com/new/wp-content/uploads/2015/03/vqprd-2016. pdf (accessed 31 July 2017).

Gade D.W., 2004. Tradition, territory, and terroir in French viniculture: Cassis, France, and Appellation Contrôlée. Annals of the Association of American Geographers, 94(4): 848-867.

Hardie J.W., 2000. Adding Value in Viticulture. Proceedings of Bureau of Rural Sciences Conference Emerging Technologies in Agriculture: From Ideas to Adoption, Melbourne, Australia, 25-26 July.

Hussain M., Cholette S. and Castaldi R.M., 2008. An analysis of globalization forces in the wine industry: implications and recommendations for wineries. Journal of Global Marketing, 21(1): 33-47.

INDV - I numeri del vino, 2017. Il valore della produzione di vino nel mondo, http://www.inumeridelvino.it/2017/07/il-valore-della-produzione-di-vino-nel-mondo-stima-indv-2016.html (accessed 31 July 2017).

ISMEA, 2017. Vini Dop (Doc-Docg) - Prezzi medi all'origine, http://www.ismeamercati.it/flex/cm/pag-
es/ServeBLOB.php/L/IT/IDPagina/2603 (accessed 31 July 2017).

Italian Wine Central, 2017a. Wine Production by Region, https://italianwinecentral.com/wine-productionin-italy-by-region/ (accessed 31 July 2017).

Italian Wine Central, 2017b. Wine Production in Italy by Color and Quality Level, https://italianwinecentral. $\mathrm{com} /$ wine-production-in-italy-by-color-and-qualitylevel/ (accessed 31 July 2017).

Kustin R. and Mitry D., 2003. Standardized multinational advertising: changes in consumer perceptions. In: Kustin R. (ed.). The Global Imperative: Marketing and Management, Theory and Applications. New York: Whittier Publications, 34-258.

Malorgio G., Camanzi L. and Grazia C., 2008. Geographical Indications and International Trade: evidence from the wine market. New Medit, 7(3): 4-13.

Malorgio G., Grazia C., Caracciolo F. and De Rosa C., 2013. Determinants of Wine-Bottling Strategic Decisions: Empirical Evidence from the Italian Wine Industry. In: Giraud-Héraud E. and Pichery M.C. (eds.) Wine Economics - Quantitative Studies and Empirical Applications. London: Palgrave Macmillan, 266-296.

Marescotti A., 2003. Typical products and rural development: Who benefits from PDO/PGI recognition?. 83rd EAAE Seminar Food Quality Products in the Advent of the 21st Century: Production, Demand and Public Policy, Chania-Crete, Greece, 4-7 September.

Miglietta P.P., De Leo F. and Massari S., 2015. Water footprint assessment of some Italian wines: A territorial perspective. International Journal of Environmental Policy and Decision Making, 1(4): 320-331.

Morrone D., 2012. The influence of sustainable development on marketing theory. Megatrend Review, 9(4): $1-20$.

Noble A.C., 1988. Analysis of wine sensory properties. In: Linskens H.F. and Jackson J.F. (eds). Wine Analysis. Berlin: Springer, 9-28.

OIV - Organisation Internationale de la Vigne et du Vin, 2017. 2017 World Vitiviniculture Situation - OIV Statistical Report on World Vitiviniculture, http://www. oiv.int/public/medias/5479/oiv-en-bilan-2017.pdf (accessed 31 July 2017).

Rapp A. and Mandery H., 1986. Wine aroma. Cellular and molecular life sciences, 42(8): 873-884.

Rocchi B. and Gabbai M., 2013. Territorial identity as a competitive advantage in wine marketing: a case study. Journal of wine research, 24(4): 291-310.

Schamel G., 2006. Geography versus brands in a global wine market. Agribusiness, 22(3): 363-374.

Schreier P. and Jennings W.G., 1979. Flavor composition of wines: a review. Critical Reviews in Food Science \& Nutrition, 12(1): 59-111. 
Smith D.E. and Mitry D.J., 2007. Cultural convergence: consumer behavioral changes in the European wine market. Journal of Wine Research, 18(2): 107-112.

Smith D. and Solgaard H., 1997. Is there a global convergence in consumer tastes? CEMS Business Review, 2: 73-84.

Strucchi A., 1908. I migliori vini d'Italia. $1^{\text {st }}$ ed., Milano: Hoepli.

Thode S.F. and Maskulka J.M., 1998. Place-based marketing strategies, brand equity and vineyard valuation. Journal of Product \& Brand Management, 7(5): 379-399.

Toma P., Miglietta P.P., Zurlini G., Valente D. and Petrosillo I., 2017. A non-parametric bootstrap-data envelopment analysis approach for environmental policy planning and management of agricultural efficiency in EU countries. Ecological Indicators, 83: 132-143.
Toma P., Massari S. and Miglietta P.P., 2016. Natural resource use efficiency and economic productivity. In: Massari S., Sonnemann G., Balkau F. (eds), Life Cycle Approaches to Sustainable Regional Development. London: Routledge, 143-148.

Tregear A., Arfini F., Belletti G. and Marescotti A., 2007. Regional foods and rural development: the role of product qualification. Journal of Rural Studies, 23(1): 12-22.

Van Leeuwen C. and Seguin G., 2006. The concept of terroir in viticulture. Journal of Wine Research, 17(1): 1-10.

Vaudour E., 2002. The quality of grapes and wine in relation to geography: Notions of terroir at various scales. Journal of Wine Research, 13(2): 117-141.

Warner K.D., 2007. The quality of sustainability: Agroecological partnerships and the geographic branding of California winegrapes. Journal of Rural Studies, 23(2): 142-155. 
Appendix 1 - Production of 65 Italian wines with Appellation of Origin (expressed in thousand hectoliters).

\begin{tabular}{|c|c|c|c|c|c|c|}
\hline Appellation of Origin & Region & 2011 & 2012 & 2013 & 2014 & 2015 \\
\hline Alcamo & Sicilia & 8 & 18 & 11 & 12 & 18 \\
\hline Alto Adige o Sud Tirol & Trentino & 295 & 287 & 317 & 278 & 288 \\
\hline Asolo Prosecco & Veneto & 11 & 16 & 17 & 50 & 62 \\
\hline Asti & Piemonte & 817 & 769 & 712 & 812 & 705 \\
\hline Barbaresco & Piemonte & 32 & 33 & 35 & 33 & 35 \\
\hline Barbera d'Alba & Piemonte & 88 & 88 & 93 & 82 & 88 \\
\hline Barbera d'Asti & Piemonte & 233 & 224 & 227 & 207 & 215 \\
\hline Barbera del Monferrato & Piemonte & 65 & 56 & 64 & 59 & 54 \\
\hline Bardolino & Veneto & 251 & 255 & 218 & 196 & 227 \\
\hline Barolo & Piemonte & 98 & 99 & 104 & 96 & 106 \\
\hline Bianco Custoza & Veneto & 119 & 115 & 112 & 95 & 104 \\
\hline Bolgheri o Bolgheri Sassicaia & Toscana & 44 & 43 & 48 & 49 & 55 \\
\hline Bonarda dell'Oltrepò Pavese & Lombardia & 196 & 169 & 189 & 181 & 185 \\
\hline Brunello di Montalcino & Toscana & 71 & 77 & 76 & 77 & 82 \\
\hline Cannonau di Sardegna & Sardegna & 90 & 100 & 87 & 87 & 100 \\
\hline Castel del Monte & Puglia & 42 & 35 & 40 & 32 & 39 \\
\hline Cerasuolo d'Abruzzo & Abruzzo & 59 & 60 & 63 & 58 & 64 \\
\hline Chianti & Toscana & 769 & 673 & 733 & 823 & 846 \\
\hline Chianti classico & Toscana & 286 & 228 & 258 & 293 & 294 \\
\hline Cirò & Calabria & 30 & 35 & 41 & 30 & 36 \\
\hline Colli Orientali del Friuli & Friuli & 85 & 77 & 72 & 73 & 87 \\
\hline Colli Piacentini & Emilia-Rom. & 109 & 92 & 105 & 103 & 91 \\
\hline Collio Goriziano & Friuli & 63 & 60 & 63 & 59 & 68 \\
\hline Conegliano Valdobbiadene & Veneto & 528 & 571 & 589 & 606 & 669 \\
\hline Cortese dell'Alto Monferrato & Piemonte & 15 & 16 & 15 & 15 & 14 \\
\hline Dolcetto d'Alba & Piemonte & 65 & 68 & 66 & 47 & 54 \\
\hline Etna & Sicilia & 12 & 22 & 25 & 27 & 27 \\
\hline Franciacorta & Lombardia & 167 & 118 & 129 & 127 & 137 \\
\hline Frascati & Lazio & 88 & 88 & 59 & 68 & 67 \\
\hline Friuli Grave & Friuli & 237 & 161 & 160 & 163 & 174 \\
\hline Gavi & Piemonte & 86 & 86 & 96 & 102 & 95 \\
\hline Gutturnio & Emilia-Rom. & 90 & 80 & 84 & 82 & 93 \\
\hline Lambrusco di Sorbara & Emilia-Rom. & 125 & 129 & 130 & 102 & 135 \\
\hline Lambrusco Grasparossa & Emilia-Rom. & 118 & 105 & 109 & 113 & 114 \\
\hline Lambrusco Salamino di Santa Croce & Emilia-Rom. & 184 & 186 & 172 & 183 & 151 \\
\hline Langhe & Piemonte & 89 & 89 & 102 & 91 & 96 \\
\hline
\end{tabular}




\begin{tabular}{|c|c|c|c|c|c|c|}
\hline Appellation of Origin & Region & 2011 & 2012 & 2013 & 2014 & 2015 \\
\hline Locorotondo & Puglia & 4 & 5 & 6 & 2 & 4 \\
\hline Lugana & Lombardia & 82 & 89 & 98 & 104 & 116 \\
\hline Marsala & Sicilia & 29 & 102 & 97 & 95 & 115 \\
\hline Modena & Emilia-Rom. & 79 & 76 & 103 & 58 & 78 \\
\hline Montepulciano d'Abruzzo & Abruzzo & 796 & 877 & 851 & 811 & 871 \\
\hline Morellino di Scansano & Toscana & 76 & 70 & 75 & 77 & 78 \\
\hline Nebbiolo d'Alba & Piemonte & 30 & 30 & 32 & 30 & 32 \\
\hline Nuragus di Cagliari & Sardegna & 20 & 15 & 17 & 16 & 16 \\
\hline Oltrepò Pavese & Lombardia & 198 & 172 & 193 & 151 & 168 \\
\hline Orvieto & Umbria & 114 & 100 & 96 & 105 & 113 \\
\hline Primitivo di Manduria & Puglia & 88 & 87 & 131 & 86 & 154 \\
\hline Prosecco & - & 1,351 & 1,798 & 2,141 & 2,241 & 3,648 \\
\hline Reggiano & Emilia-Rom. & 154 & 135 & 148 & 156 & 158 \\
\hline Roero & Piemonte & 47 & 48 & 52 & 47 & 53 \\
\hline Rosso Piceno & Marche & 82 & 71 & 74 & 67 & 89 \\
\hline Rosso Conero & Marche & 13 & 8 & 14 & 15 & 13 \\
\hline Salice Salentino & Puglia & 140 & 141 & 146 & 77 & 117 \\
\hline San Severo & Puglia & 34 & 31 & 28 & 23 & 22 \\
\hline Soave & Veneto & 412 & 530 & 517 & 506 & 422 \\
\hline Trebbiano d'Abruzzo & Abruzzo & 188 & 197 & 187 & 166 & 191 \\
\hline Trentino & Trentino & 563 & 520 & 606 & 502 & 653 \\
\hline Valdadige o Etschtaler & Trentino & 100 & 97 & 117 & 114 & 104 \\
\hline Valpolicella & Veneto & 356 & 354 & 380 & 425 & 378 \\
\hline Venezia & Veneto & 137 & 106 & 108 & 109 & 162 \\
\hline Verdicchio dei Castelli di Jesi & Marche & 146 & 129 & 154 & 149 & 165 \\
\hline Vermentino di Gallura & Sardegna & 42 & 47 & 51 & 51 & 45 \\
\hline Vermentino di Sardegna & Sardegna & 99 & 95 & 121 & 101 & 112 \\
\hline Vernaccia di San Gimignano & Toscana & 42 & 37 & 39 & 44 & 40 \\
\hline Vino Nobile di Montepulciano & Toscana & 62 & 55 & 58 & 65 & 54 \\
\hline
\end{tabular}

Source: based on data extracted from Federdoc (2012, 2013, 2014, 2015, 2016). 
Appendix 2 - Declared area for 65 Italian wines with Appellation of Origin (expressed in hectares).

\begin{tabular}{|c|c|c|c|c|c|c|}
\hline Appellation of Origin & Region & 2011 & 2012 & 2013 & 2014 & 2015 \\
\hline Alcamo & Sicilia & 337 & 289 & 163 & 246 & 287 \\
\hline Alto Adige o Sud Tirol & Trentino & 4,490 & 4,585 & 4,622 & 4,607 & 4,669 \\
\hline Asolo Prosecco & Veneto & 138 & 216 & 190 & 698 & 931 \\
\hline Asti & Piemonte & 9,803 & 9,490 & 9,045 & 9,537 & 9,404 \\
\hline Barbaresco & Piemonte & 678 & 684 & 728 & 733 & 738 \\
\hline Barbera d'Alba & Piemonte & 1,438 & 1,565 & 1,598 & 1,589 & 1,561 \\
\hline Barbera d'Asti & Piemonte & 4,367 & 3,546 & 3,600 & 3,285 & 4,727 \\
\hline Barbera del Monferrato & Piemonte & 1,172 & 788 & 910 & 837 & 765 \\
\hline Bardolino & Veneto & 3,000 & 2,932 & 2,816 & 2,428 & 2,336 \\
\hline Barolo & Piemonte & 1,945 & 1,977 & 2,054 & 2,067 & 2,073 \\
\hline Bianco Custoza & Veneto & 1,224 & 1,242 & 1,345 & 1,197 & 1,258 \\
\hline Bolgheri o Bolgheri Sassicaia & Toscana & 834 & 926 & 888 & 956 & 994 \\
\hline Bonarda dell'Oltrepò Pavese & Lombardia & 2,839 & 2,631 & 2,697 & 2,572 & 2,583 \\
\hline Brunello di Montalcino & Toscana & 1,920 & 1,958 & 1,915 & 1,920 & 1,962 \\
\hline Cannonau di Sardegna & Sardegna & 1,164 & 2,187 & 2,187 & 2,236 & 2,185 \\
\hline Castel del Monte & Puglia & 623 & 334 & 417 & 310 & 395 \\
\hline Cerasuolo d'Abruzzo & Abruzzo & 689 & 684 & 691 & 654 & 699 \\
\hline Chianti & Toscana & 14,645 & 14,183 & 14,171 & 14,296 & 14,413 \\
\hline Chianti classico & Toscana & 6,783 & 6,518 & 6,576 & 6,653 & 6,590 \\
\hline Cirò & Calabria & 710 & 423 & 487 & 357 & 740 \\
\hline Colli Orientali del Friuli & Friuli & 1,832 & 1,807 & 1,750 & 1,688 & 1,832 \\
\hline Colli Piacentini & Emilia-Rom. & 1,661 & 1,658 & 2,610 & 1,220 & 1,065 \\
\hline Collio Goriziano & Friuli & 1,277 & 1,234 & 1,262 & 1,203 & 1,257 \\
\hline Conegliano Valdobbiadene & Veneto & 5,751 & 6,259 & 6,580 & 6,860 & 7,195 \\
\hline Cortese dell'Alto Monferrato & Piemonte & 248 & 223 & 210 & 216 & 202 \\
\hline Dolcetto d'Alba & Piemonte & 1,265 & 1,391 & 1,359 & 1,315 & 1,218 \\
\hline Etna & Sicilia & 568 & 645 & 656 & 772 & 760 \\
\hline Franciacorta & Lombardia & 2,629 & 2,580 & 2,530 & 2,445 & 2,633 \\
\hline Frascati & Lazio & 1,187 & 839 & 865 & 890 & 830 \\
\hline Friuli Grave & Friuli & 3,101 & 2,879 & 2,380 & 2,699 & 2,514 \\
\hline Gavi & Piemonte & 1,424 & 1,455 & 1,460 & 1,474 & 1,507 \\
\hline Gutturnio & Emilia-Rom. & 1,314 & 1,271 & 1,036 & 1,014 & 1,153 \\
\hline Lambrusco di Sorbara & Emilia-Rom. & 1,261 & 1,937 & 1,185 & 957 & 1,076 \\
\hline Lambrusco Grasparossa & Emilia-Rom. & 1,200 & 1,333 & 1,120 & 1,212 & 907 \\
\hline Lambrusco Salamino di Santa Croce & Emilia-Rom. & 1,519 & 2,532 & 1,521 & 1,648 & 1,388 \\
\hline Langhe & Piemonte & 1,533 & 1,264 & 1,371 & 1,448 & 1,519 \\
\hline Locorotondo & Puglia & 107 & 82 & 81 & 46 & 63 \\
\hline
\end{tabular}




\begin{tabular}{|c|c|c|c|c|c|c|}
\hline Appellation of Origin & Region & 2011 & 2012 & 2013 & 2014 & 2015 \\
\hline Lugana & Lombardia & 1,015 & 1,050 & 1,126 & 1,185 & 1,330 \\
\hline Marsala & Sicilia & 1,480 & 1,672 & 1,479 & 1,737 & 1,836 \\
\hline Modena & Emilia-Rom. & 648 & 1,017 & 774 & 667 & 841 \\
\hline Montepulciano d'Abruzzo & Abruzzo & 9,203 & 9,332 & 9,264 & 9,055 & 9,559 \\
\hline Morellino di Scansano & Toscana & 1,424 & 1,414 & 1,305 & 1,315 & 1,355 \\
\hline Nebbiolo d'Alba & Piemonte & 523 & 649 & 700 & 713 & 748 \\
\hline Nuragus di Cagliari & Sardegna & 175 & 131 & 152 & 144 & 146 \\
\hline Oltrepò Pavese & Lombardia & 3,212 & 2,912 & 2,929 & 2,451 & 2,783 \\
\hline Orvieto & Umbria & 1,813 & 1,942 & 1,531 & 1,676 & 1,804 \\
\hline Primitivo di Manduria & Puglia & 2,228 & 2,050 & 2,345 & 2,366 & 3,100 \\
\hline Prosecco & - & 11,215 & 14,285 & 17,490 & 19,108 & 23,979 \\
\hline Reggiano & Emilia-Rom. & 1,409 & 1,072 & 1,176 & 1,394 & 1,256 \\
\hline Roero & Piemonte & 724 & 878 & 1,015 & 1,028 & 1,052 \\
\hline Rosso Piceno & Marche & 1,318 & 1,161 & 1,140 & 1,124 & 1,340 \\
\hline Rosso Conero & Marche & 225 & 173 & 208 & 237 & 207 \\
\hline Salice Salentino & Puglia & 2,067 & 2,196 & 2,215 & 1,564 & 1,866 \\
\hline San Severo & Puglia & 342 & 315 & 287 & 251 & 233 \\
\hline Soave & Veneto & 4,523 & 5,645 & 5,301 & 5,438 & 5,827 \\
\hline Trebbiano d'Abruzzo & Abruzzo & 2,133 & 2,139 & 2,122 & 1,968 & 2,195 \\
\hline Trentino & Trentino & 6,827 & 6,685 & 6,589 & 6,615 & 7,367 \\
\hline Valdadige o Etschtaler & Trentino & 848 & 979 & 1,110 & 1,100 & 1,041 \\
\hline Valpolicella & Veneto & 6,833 & 7,061 & 7,282 & 7,435 & 7,660 \\
\hline Venezia & Veneto & 1,559 & 1,141 & 1,277 & 1,457 & 1,967 \\
\hline Verdicchio dei Castelli di Jesi & Marche & 2,104 & 2,036 & 2,013 & 2,015 & 2,040 \\
\hline Vermentino di Gallura & Sardegna & 623 & 865 & 1,107 & 1,180 & 1,241 \\
\hline Vermentino di Sardegna & Sardegna & 762 & 851 & 1,081 & 902 & 1,522 \\
\hline Vernaccia di San Gimignano & Toscana & 714 & 718 & 725 & 740 & 719 \\
\hline Vino Nobile di Montepulciano & Toscana & 1,200 & 1,172 & 1,040 & 1,160 & 1,115 \\
\hline
\end{tabular}

Source: based on data extracted from Federdoc (2012, 2013, 2014, 2015, 2016). 
Appendix 3 - Average annual prices at source for 65 Italian wines with Appellation of Origin (expressed in $€ / \mathrm{hl}$ ).

\begin{tabular}{|c|c|c|c|c|c|c|}
\hline Appellation of Origin & Region & 2011 & 2012 & 2013 & 2014 & 2015 \\
\hline Alcamo & Sicilia & 63 & 76 & 90 & 92 & 99 \\
\hline Alto Adige o Sud Tirol & Trentino & 210 & 192 & 202 & 261 & 276 \\
\hline Asolo Prosecco & Veneto & 190 & 209 & 206 & 205 & 222 \\
\hline Asti & Piemonte & 153 & 169 & 173 & 171 & 160 \\
\hline Barbaresco & Piemonte & 291 & 274 & 266 & 292 & 356 \\
\hline Barbera d'Alba & Piemonte & 113 & 116 & 134 & 118 & 137 \\
\hline Barbera d'Asti & Piemonte & 83 & 92 & 95 & 100 & 112 \\
\hline Barbera del Monferrato & Piemonte & 68 & 83 & 88 & 85 & 88 \\
\hline Bardolino & Veneto & 78 & 85 & 81 & 83 & 91 \\
\hline Barolo & Piemonte & 541 & 677 & 694 & 706 & 750 \\
\hline Bianco Custoza & Veneto & 67 & 70 & 74 & 83 & 94 \\
\hline Bolgheri o Bolgheri Sassicaia & Toscana & 142 & 131 & 149 & 177 & 240 \\
\hline Bonarda dell'Oltrepò Pavese & Lombardia & 63 & 66 & 67 & 68 & 80 \\
\hline Brunello di Montalcino & Toscana & 617 & 675 & 710 & 755 & 880 \\
\hline Cannonau di Sardegna & Sardegna & 131 & 169 & 167 & 100 & 104 \\
\hline Castel del Monte & Puglia & 70 & 77 & 78 & 69 & 67 \\
\hline Cerasuolo d'Abruzzo & Abruzzo & 47 & 63 & 79 & 67 & 73 \\
\hline Chianti & Toscana & 101 & 103 & 127 & 147 & 134 \\
\hline Chianti classico & Toscana & 142 & 131 & 149 & 177 & 240 \\
\hline Cirò & Calabria & 142 & 134 & 139 & 139 & 138 \\
\hline Colli Orientali del Friuli & Friuli & 118 & 136 & 131 & 127 & 135 \\
\hline Colli Piacentini & Emilia-Rom. & 72 & 82 & 99 & 100 & 96 \\
\hline Collio Goriziano & Friuli & 118 & 136 & 131 & 127 & 135 \\
\hline Conegliano Valdobbiadene & Veneto & 190 & 209 & 206 & 205 & 222 \\
\hline Cortese dell'Alto Monferrato & Piemonte & 55 & 68 & 80 & 78 & 91 \\
\hline Dolcetto d'Alba & Piemonte & 115 & 115 & 102 & 81 & 110 \\
\hline Etna & Sicilia & 117 & 127 & 136 & 140 & 126 \\
\hline Franciacorta & Lombardia & 185 & 201 & 206 & 210 & 231 \\
\hline Frascati & Lazio & 53 & 64 & 78 & 88 & 90 \\
\hline Friuli Grave & Friuli & 72 & 70 & 84 & 88 & 93 \\
\hline Gavi & Piemonte & 149 & 150 & 153 & 163 & 228 \\
\hline Gutturnio & Emilia-Rom. & 70 & 71 & 84 & 80 & 80 \\
\hline Lambrusco di Sorbara & Emilia-Rom. & 56 & 66 & 66 & 84 & 83 \\
\hline Lambrusco Grasparossa & Emilia-Rom. & 52 & 56 & 56 & 76 & 76 \\
\hline Lambrusco Salamino di Santa Croce & Emilia-Rom. & 47 & 53 & 54 & 70 & 70 \\
\hline Langhe & Piemonte & 104 & 119 & 129 & 134 & 143 \\
\hline
\end{tabular}




\begin{tabular}{|c|c|c|c|c|c|c|}
\hline Appellation of Origin & Region & 2011 & 2012 & 2013 & 2014 & 2015 \\
\hline Locorotondo & Puglia & 65 & 75 & 82 & 64 & 62 \\
\hline Lugana & Lombardia & 67 & 70 & 74 & 83 & 94 \\
\hline Marsala & Sicilia & 66 & 79 & 96 & 103 & 115 \\
\hline Modena & Emilia-Rom. & 46 & 63 & 74 & 56 & 81 \\
\hline Montepulciano d'Abruzzo & Abruzzo & 47 & 63 & 79 & 67 & 73 \\
\hline Morellino di Scansano & Toscana & 122 & 117 & 138 & 162 & 187 \\
\hline Nebbiolo d'Alba & Piemonte & 127 & 137 & 181 & 184 & 219 \\
\hline Nuragus di Cagliari & Sardegna & 44 & 73 & 89 & 84 & 80 \\
\hline Oltrepò Pavese & Lombardia & 106 & 109 & 107 & 104 & 107 \\
\hline Orvieto & Umbria & 56 & 61 & 83 & 83 & 90 \\
\hline Primitivo di Manduria & Puglia & 70 & 77 & 78 & 69 & 67 \\
\hline Prosecco & - & 159 & 155 & 120 & 116 & 176 \\
\hline Reggiano & Emilia-Rom. & 45 & 55 & 69 & 67 & 67 \\
\hline Roero & Piemonte & 216 & 199 & 191 & 149 & 115 \\
\hline Rosso Piceno & Marche & 54 & 58 & 58 & 58 & 58 \\
\hline Rosso Conero & Marche & 113 & 113 & 113 & 113 & 113 \\
\hline Salice Salentino & Puglia & 70 & 77 & 78 & 69 & 67 \\
\hline San Severo & Puglia & 65 & 74 & 78 & 63 & 176 \\
\hline Soave & Veneto & 65 & 77 & 89 & 87 & 84 \\
\hline Trebbiano d'Abruzzo & Abruzzo & 34 & 51 & 68 & 44 & 44 \\
\hline Trentino & Trentino & 127 & 138 & 145 & 137 & 144 \\
\hline Valdadige o Etschtaler & Trentino & 140 & 164 & 170 & 166 & 168 \\
\hline Valpolicella & Veneto & 155 & 250 & 244 & 231 & 239 \\
\hline Venezia & Veneto & 118 & 136 & 131 & 127 & 135 \\
\hline Verdicchio dei Castelli di Jesi & Marche & 69 & 75 & 88 & 83 & 89 \\
\hline Vermentino di Gallura & Sardegna & 70 & 115 & 173 & 139 & 137 \\
\hline Vermentino di Sardegna & Sardegna & 47 & 77 & 116 & 93 & 92 \\
\hline Vernaccia di San Gimignano & Toscana & 124 & 135 & 137 & 149 & 141 \\
\hline Vino Nobile di Montepulciano & Toscana & 272 & 283 & 329 & 325 & 393 \\
\hline
\end{tabular}

Source: based on data extracted from ISMEA (2017). 